Akreditasi Risetdikti,

No 30/E/KPT/2019 (Sinta 4).

DOI: https://10.31294/jkom

\title{
Representasi Maskulinitas Tokoh Lelaki Dalam Film Susah Sinyal
}

\author{
Jusuf Fadilah $^{1}$, Widarti ${ }^{2}$, Dina Andriana ${ }^{3}$ \\ Universitas Bina Sarana Informatika ${ }^{1}$ \\ e-mail: jusuf.jff@bsi.ac.id \\ Universitas Bina Sarana Informatika ${ }^{2}$ \\ e-mail: widarti.wdr@bsi.ac.id \\ Universitas Bina Sarana Informatika ${ }^{3}$ \\ e-mail: dina.daa@bsi.ac.id
}

Diterima : 2021-01-02

Direvisi : 2021-02-20

Diterima : 2021-08-01

\begin{abstract}
This scientific research aims to determine the connotation and extension of Iwan, one of the supporting roles in the movie "Susah Sinyal", and the masculinity ideology of social development based on the analysis of Roland Barthes. The analytical methods used use qualitative research methods to give priority to descriptive interpretation and analysis of authors, and tend to give priority to analysis to generate more prominent thematic perspectives. This research has taken 10 photos in the movie "Susah Sinyal". These photos are inseparable from Iwan's role and are marked by explicit signs, to examine the implicit meaning of these images, from the connotation, extension, and mythological meaning spread in society Interpretation. The views and idols of people who were hyped up in their time.
\end{abstract}

Keywords: Maskulinitas, konotasi, denotasi, mitos

\section{PENDAHULUAN}

Gagasan untuk menciptakan film adalah dari para seniman pelukis. Dengan ditemukannya cinematography telah minimbulkan gagasan kepada mereka untuk menghidupkan gambar-gambar yang mereka lukis. Dan lukisan-lukisan itu bisa menimbulkan hal yang lucu dan menarik, karena dapat disuruh memegang peran apa saja, yang tidak mungkin diperankan oleh manusia

Film adalah fenomena sosial, psikologi, dan estetika yang kompleks yang merupakan dokumen yang terdiri dari cerita dan gambar yang diiringi kata-kata dan musik. Sehingga film merupakan produksi yang multi dimensional dan kompleks. Kehadiran film di tengah kehidupan manusia sekarang ini semakin penting dan sastra dengan media lain. Dibanding media cetak seperti novel, film lebih mudah dipahami karena merupakan media audio visual yang diminati banyak orang.

Beberapa literatur di temukan beberapa film mencitrakan sosok perempuan, yaitu "Wanita Berkalung Sorban" (2009), "Marlina Si Pembunuh dalam Empat Babak" (2017), sosok ibu dalam film "Pengabdi Setan" (2017) dan Susah Sinyal (2017). Ternyata tak hanya karakter Wanita yang sering diperbincangkan, sosok lelaki pun menarik untuk dijadikan topi pembahasan kali ini dengan membahas mengenai salah satu karakter lelaki dalam film Susah Sinyal .

Pemilihan film Susah Sinyal karya Ernest Prakasa dikarenakan film ini salah satu film terbaik pada penghargaan IBOMA 2018 dengan menyabet tiga penghargaan sekaligus. Pada film Susah Sinyal, Ernest Prakasa mengetengahkan sosok Wanita karir yang menjadi pengacara sukses namun sosok seorang single parent. Dimana konflik mulai timbul saat sosok Wanita karir ini tidak bisa meluangkan waktu bagi anak tunggalnya.

Hal tersebut menjadikan Kiara tumbuh sebagai remaja pemberontak yang lebih banyak melampiaskan emosinya ke media sosial. Di tempat kerja, Ellen memiliki seorang sahabat karib seperjuangan bernama Iwan, Ia merupakan sosok lelaki dan sahabat satu-satunya yang paling mengerti mengenai dirinya. Berbeda dengan Ellen yang sudah pernah menikah dan memiliki anak, Iwan baru akan menikah dengan sang calon yang masih menyelesaikan studinya. Tak jarang Ibu Iwan menelepon untuk menanyakan pendapat Iwan mengenai atribrut persiapan menikah, mulai dari catering, jenis tea pai yang diinginkan, bahkan warna kostum yang pernikahan. 
Di balik sosok Ellen selaku pemeran utama film, tenyata sosok Iwan sebagai pemeran pembantu memiliki peran penting dalam cerita kehidupan Ellen. Menepi dari isu hubungan ibu dan anak yang dibawakan dalam film Susah Sinyal, nampaknya ada satu hal menarik. Berbeda dari banyak kisah yang menceritakan mengenai patriarki bahkan lemahnya seorang perempuan. Film ini justru memberikan warna lain dengan menampilkan sosok maskulinitas yang di perankan oleh Iwan. Dibeberapa kesempatan, apabila membicarakan mengenai dominan dan patriarki, justru Ellen lebih mendominasi. Di film ini, lelaki bukan lagi ditampilkan sebagai kaum patriarki yang selalu menang atas perempuan.

Berdasarkan pemaparan di atas, film Susah Sinyal menjadi film yang menarik untuk diteliti terkait repreentasi maskulinitas yang dibawakan oleh pemeran pembantu, Iwan. Dalam penelitian ini, peneliti melakukan pendekatan kualitatif dengan metode Roland Barthes dengan membaca tanda-tanda yang mucul dalam film.

Maskulinitas dapat didefinisikan sebagai cara menjadi pria sesuai apa yang diterima oleh masyarakat. MacInnes menyebutkan bahwa maskulinitas terbentuk karena adanya fantasi bagaimana seorang pria itu seharusnya seperti apa dan bagaimana. Maskulinitas terkonstruksi agar orang-orang tahu harus bagaimana dalam hidupnya. Contoh yang paling umum adalah seorang pria dilarang menangis karena menangis adalah sifat perempuan.

Pencitraan maskulinitas sendiri berbeda disetiap periodenya. Dalam Exhibiting Masculinity, Sean Nixon menjelaskan bahwa di era 1980an-1990an, ciri-ciri visual maskulin biasanya adalah pria dengan tubuh tegap dan kekar, memiliki dada dan lengan yang berotot. Hal tersebut dapat dilihat dalam beberapa kampanye produk celana jeans untuk pria, yang memperlihatkan bagian atas tubuh model yang kekar dan berotot. Sedangkan menurut Metcalf dan Humphries, maskulinitas memiliki karakter yang keras/kasar, berjiwa kompetitif, dan cenderung emosional dan dingin. Selain itu maskulinitas juga dicirikan dengan menjaga jarak terhadap hubungan yang melibatkan emosi, baik terhadap ayah maupun pasanganny.

Selain dikategorikan oleh fisik dan emosi, maskulinitas juga dapat dicirikan lewat gaya berpakaian. Dalam era 1980an-1990an di Amerika, menurut Nixon gaya berpakaian maskulin terbagi kedalam tiga kategori, yaitu gaya jalanan, gaya Italia-Amerika, dan gaya konservatif Inggris. Dalam gaya jalanan ada perpaduan antara kelembutan anak laki-laki dan ketangguhan pria dewasa. Sedangkan dalam gaya Italia-Amerika maskulin cenderung digambarkan dengan gaya macho. Dan dalam kategori gaya konservatif Inggris, lebih ditekankan pada kualitas dan tradisi yang dapat terlihat dari bahan-bahan yang dipakai.

\section{METODOLOGI PENELITIAN}

Film Susah Sinyal karya Ernest merupakan film yang menarik untuk diteliti terkait representasi maskulinitas dalam film tersebut. Dalam penelitian ini peneliti menggunakan pendekatan secara kualitatif dengan metode analisis semiotika Roland Barthes. Analisis semiotika Roland Barthes merupakan teknik analisis dengan membaca tanda-tanda yang ditampilkan dalam film dengan mengulik tiga tingkatan, yakni konotasi, denotasi dan sejarah(mitos) yang dihadirkan.

\section{HASIL DAN PEMBAHASAN}

Pada bagian ini, dijelaskan hasil penelitian dan pada saat yang sama diberikan pembahasan yang komprehensif. Berikut penelitian berdasar tiga struktur analisis semiotika Roland Barthes, yakni pembacaan secara konotasi, denotasi, dan mitos.

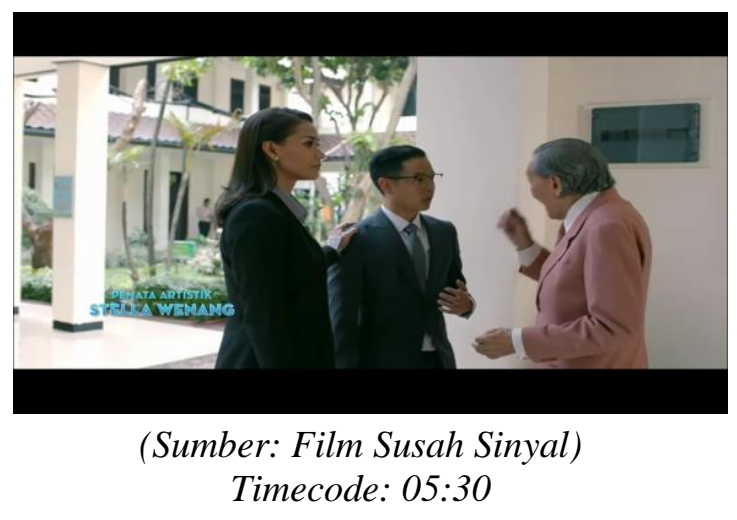

Makna denotasi: Gambar ini mengawali perkenalan Iwan kepada penonton, Iwan hadir sebagai rekan kerja Ellen dan rekan dalam membangun project perusahaan baru. Pada gambar ini muncul makna denotasi dari Iwan seorang laki-laki yang sedang menjelaskan pembenaran terhadapan ucapannya di depan sang bos. Sedangkan Ellen awalnya mencengkram lengan Iwan kini berganti menepuk bahu lelaki tersebut. 
Makna kobotasi: Dari makna denotasi tersebut muncul makna konotasi dominasi dan kesetaraan gender. Di awal scene nampak Ellen mendominasi pembicaraan dengan sang bos, sedangkan Iwan berjalan di belakang mereka berdua hanya tersenyum dan sesekali menyahut, lalu di frame yang di screenshot di atas Iwan nampak lebih lemah dibanding Ellen.

Mitos: Apabila dikaitkan dengan maskulinitas patriarki yang lama ini dianut Negara berkembang macam Indonesia, kaum lelaki lebih banyak mendominasi dan gagah atau lebih kuat daripada kaum perempuan.

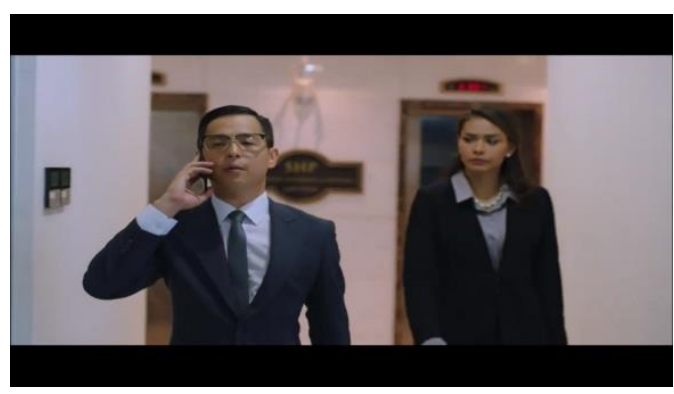

(Sumber: Film Susah Sinyal)

Timecode: 09:30

Makna denotasi: dapat diuraikan dari potongan gambar diatas adalah Ellen dan Iwan sedang berjalan keluar dari lift, lalu Ibu Iwan menelepon menanyakan menu catering apa yang diinginkan untuk pernhikahan Iwan. Iwan menjawab menu masakan cina, dan Ibunya bertanya kembali, menu masakan cina yang bagaimana karena ada banyak menu masakan cina.

Makna konotasi: Dapat diuraikan secara makna konotasi bahwa lelaki cenderung cuek, bahkan untuk membicarakan persiapan pernikahan sekalipun. Dan dengan setelan jas yang gagah menunjukan sisi maskulin dari Iwan sebagai seorang lelaki yang rapi dan stylish.

Mitos: Pada dasarnya lelaki cenderung bersikap cuek, namun maskulinitas yang diperlihatkan oleh Iwan adalah sosok lelaki pekerja yang tetap mengangkat telepon dari Ibunya meski disaat ia sedang berada di kantor. Selain itu, maskulinitas seorang lelaki masa kini diperlihatkan dengan tampilan atau busana rapi yang dikenakan.

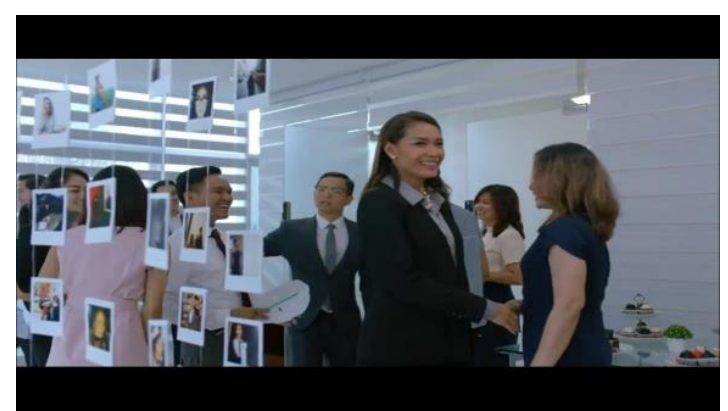

(Sumber: Film Susah Sinyal) Timecode: 10:20

Makna denotasi: Ellen dan Iwan akan memulai project baru mereka dengan mendirikan perusahaan baru, saat memasuki ruangan, keduanya mendapat surprise dari rekan-rekan di perusahaan lama. Sayang, rupanya hanya Ellen yang diberi selamat, padahal project ini merupakan project Ellen bersama Iwan.

Makna konotasi: Dari gambar diatas dijelaskan secara konotasi bahwa kaum lelaki tidak selalu mendominasi bahkan bersikap patriarki, hal tersebut terbukti adanya bahwa Ellen nampak lebih mendominasi Iwan.

Mitos: Maskulinitas lelaki yang dianggap kaum lebih kuat dan mendominasi bergeser, di era sekarang, lelaki dianggap maskulin apabila mau mengalah kepada perempuan dan mengakui adanya kesetaraan gender.

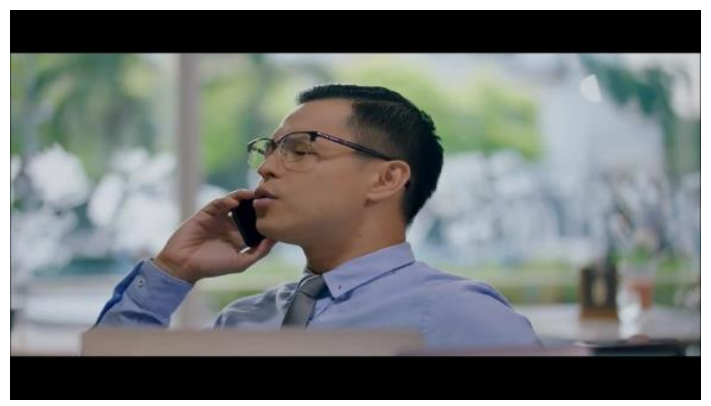

(Sumber: Film Susah Sinyal)

Timecode: 13:09

Makna denotasi: Gambar maskulinitas yang ditawarkan dalam frame diatas adalah Iwan yang sedang di café bersama Ellen dan membicarakan project mereka, lalu Iwan mendapati telepon dari ibunya yang lagi-lagi membahas tentang pernikahan. Ditanya tentang warna kostum yang diinginkan, Iwan menjawab pertanyaan Ibunya dengan memberikan jawaban sepenuhnya kepada sang Ibu yang menanyakan warna yang diinginkan,

Makna konotasi: Iwan dan sang ibu membicarakan warna yang diingkan untuk 
kostum pernikahan Iwan. Nampaknya, seperti lelaki kebanyakan, Iwan tak begitu tahu banyak warna. Diketahui, kaum lelaki tidak mengetahui banyak tentang warna dibanding perempuan. Setidaknya Iwan menyempatkan diri untuk mengangkat telepon dari sang Ibu dan hal tersebut menonjolkan kemaskulinannya yang mana walau sedang sibuk dengan pekerjaan, Ia tetap mau menyempatkan diri mengangkat telepon dari sang Ibu.

Mitos: Pria dan wanita melihat warna secara berbeda, dalam sebuah artikel dari situs di internet, membaca secara psikologi, wanita cenderung dapat lebih banyak dan rinci dalam membaca warna. Seperti contoh, wanita akan menyebut warna magenta dan carnation adalah warna yang berbeda, sedangkan, lelaki cenderung mengelompokan dua warna tersebut dan menyebutnya dengan warna pink. Dari perdebatan warna melalui telepon yang dilakukan Iwan dengan sang Ibu, hal tersebut menunjukan sosok maskulinitas Iwan yang mau mendengarkan dan meluangkan waktu untuk sang Ibu. Iwan mau mendengarkan ibunya meskipun membicarakan hal yang remeh.

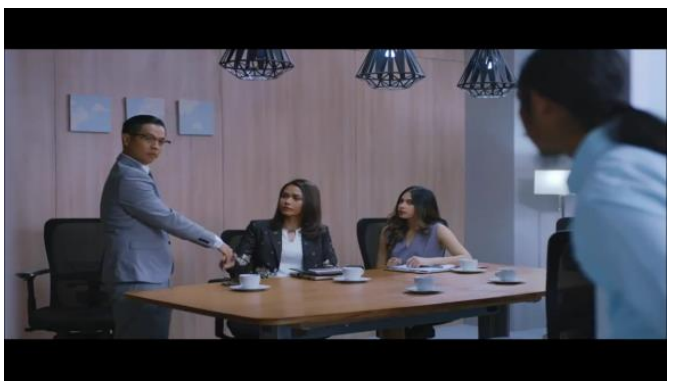

(Sumber: Film Susah Sinyal)

Timecode: 25:05

Makna denotasi: Screenshot diatas memiliki makna denotasi dengan menampilkan Iwan yang bersikukuh untuk mengambil project dari salah satu klien, sedangkan Ellen berbanding terbalik dengan kemauan Iwan, Ia justru ingin mundur untuk tidak mengambil project dari klien. Perselisihan terjadi diantara keduanya, Iwan berusaha keras meyakinkan Ellen untuk mengambil project tersebut hingga akhirnya Ellen setuju mengambil project tersebut dengan catatan bahwa Iwan akan bertanggung jawab atas apapun yang terjadi.

Makna konotasi: Dari percakapan keduanya memiliki maknan konotasi bahwa, Ellen akan mengambil project sesuai yang Iwan harapkan, namun Ia meminta Iwan bertanggung jawab atas langkah yang mereka pilih untuk mengambil project dari klien pertama mereka.

Mitos: perempuan melangkah, lelakilah yang tetap harus bertanggung jawab atas keputusan atau langkah yang diambil sang perempuan. Lelaki harus bisa melindungi dan bertanggung jawab. Dan disini Iwan berdiri menunjukan Iwan sebagai lelaki memiliki kedudukan lebih tinggi dari dua orang perempuan rekan kerjanya yang duduk walau Ia hanya lelaki sendiri.

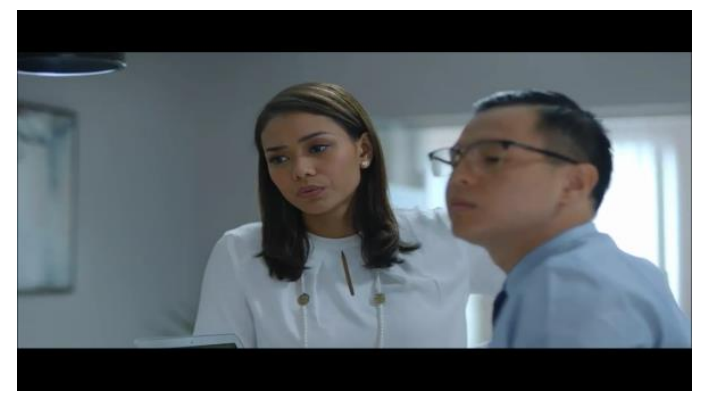

(Sumber: Film Susah Sinyal)

Timecode: $36: 40$

Makna denotasi: Ellen bimbang untuk meninggalkan projectnya sebentar dan berlibur dengan Kiara, sang anak. Project pertama ini dinilai sangat penting untuk mendongkrak eksistensi perusahaan mereka, di sisi lain, Ellen bimbang setelah permasalahan yang terjadi antara Ellen dan Kiara, sang guru BK menyarankan ibu dan anak ini meluangkan waktu bersama. Sebagai sahabat yang paling mengerti, Iwan berusaha menguatkan Ellen untuk tidak lagi bimbang untuk berlibur sejenak dengan sang anak.

Makna konotasi: Makna konotasi yang di hadirkan adalah tatkala Kiara pergi, Iwan akan bertanggung jawab terhadap project mereka. Lelaki sebagai penanggung jawab. Disini juga memperlihatkan betapa bijaknya Iwan menasehati sang sahabat.

Mitos: Mitos yang terkait, kini lelaki maskulin ditampilkan dengan adanya jiwa mereka yang bijak dan dapat bertanggung jawab. Dibutuhkan rasa pecaya diri untuk memimpin dan bertanggung jawab dalam diri seorang lelaki yang maskulin. 


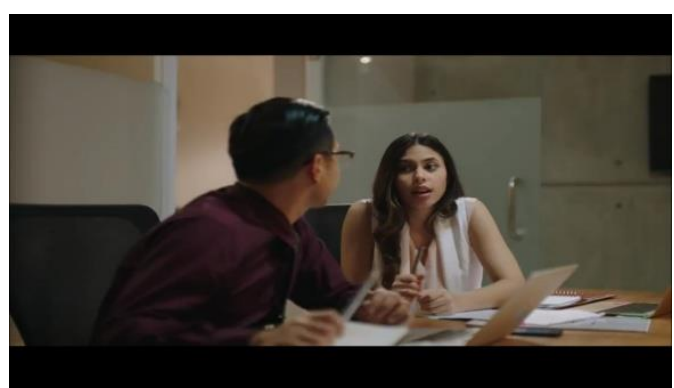

(Sumber: Film Susah Sinyal) Timecode: 50:20

Makna denotasi: Dari gambar diatas, Iwan dan seorang anak magang sedang menyelesaikan berkas-berkas untuk project pertama perusahaan. Namun, lagi-lagi Ibu Iwan menelepon, kali ini menanyakan daun apa yang ingin digunakan dalam acara tea pai pernikahannya. Iwan menjawab dengan alakadarnya, namun sang ibu meminta jawaban yang rinci.

Makna konotasi: Kembali seperti permasalahan sebelumnya, lelaki ditunjukan menyukai sesuatu yang simpel. Disini menampakan juga kebudayaan adat keturunan cina ketika menikah yakni diadakannya rangkaian acara tea pai dalam pernikahan.

Mitos: Maskulinitas seorang lelaki dilihat dari bagaimana kedekatannya dengan keluarga, terlebih sang Ibu. Walau cenderung cuek, lelaki maskulin yang ditampilkan oleh sosok Iwan adalah bagaimana Ia dapat menempatkan diri dalam menanggapi telepontelepn dari sang Ibu tatkala di tengah kesibukannya.

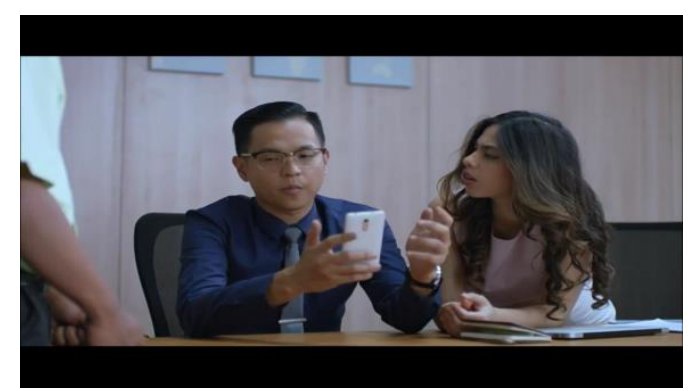

(Sumber: Film Susah Sinyal)

Timecode: 01:13:17

Makna denotasi: Klien dari project pertama nampaknya terlilit masalah, dari sebuah akun media sosial yang mengulik tentang selebriti, "Lambe Turah", nama akun tersebut, terdapat sebuah postingan negatif mengenai klien mereka yang tak lain adalah seorang selebriti bernama Gisela. Iwan mendapat informasi negatif tersebut dari Office boy kantor.

Makna konotasi: Kemaskulinan dalam diri Iwan nampak. Dari gambar diatas dapat dimaknakan secara konotasi bahwa Iwan tak tahu menahu adanya akun social media macam Lambe Turah yang menginformasikan berita terkini tentang artis.

Mitos: Hal tersebut bermakna konotasi, lelaki dengan strata sosial kelas atas seperti Iwan tak ada waktu untuk membuka dan mengikuti informasi dari akun macam lambe turah. Lelaki maskulin cenderung tidak suka gosip, itulah yang nampaknya ingin ditampilkan.

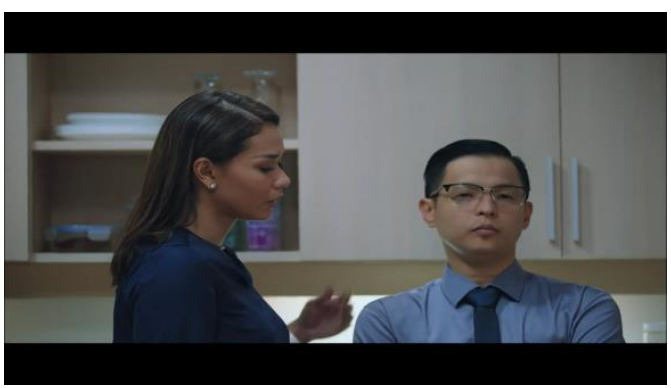

(Sumber: Film Susah Sinyal)

Timecode: 1:16: 40

Makna denotasi: Ellen meminta bantuan Iwan unutuk menemani Kirana mencari kain untuk bahan kostum lombanya. Karena Ellen akan melakukan wawancara terhadap klien mereka. Awalnya Iwan menolak untuk menemani Kirana dan ia mengajukan diri untuk mewawancarai klien. Ellen menolak dan bersikukuh untuk mewawancarai klien dan meminta Iwan menemanani anaknya mencari kain. Akhirnya Iwan mengalah untuk menemani anak Ellen memilih kain.

Makna konotasi: Makna konotasi yang ditampilkan, gambaran maskulinitas yang diperlihatkan oleh seorang lelaki adalah dirinya yang mau mengalah terhadap perempuan.

Mitos: Dari zaman ke zaman, nilai pandang masyarakat terhadap lelaki maskulin bergeser. Lelaki yang maskulin tidak hanya handal dalam mengurus pekerjaan kantor, namun dilihat dari bagaimana Ia mau dan mampu turun tangan mengurusi hal kecil yang biasa dilakoni perempuan seorang ibu, yakni menemani anak belanja. 


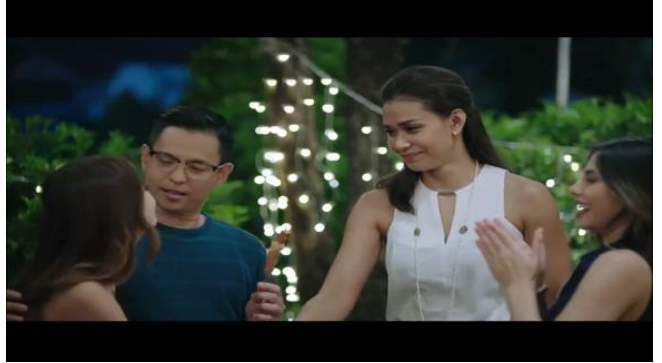

(Sumber: Film Susah Sinyal)

Timecode: 01:45:16

Makna denotasi: Berlatar di sebuah pesta di pekarangan rumah Ellen, Iwan dan sang calon istri bercerita mengenai Meteor Garden, sebuah drama yang pernah popular di zamannya. Sang calon istri menceritakan bahwa tersebut.

Makna konotasi: Secara konotasi bermakna maskulinitas lelaki pada zaman drama Meteor Garden ditunjukan seperti yang terlukis pada karakter tokoh dan penampilan tokoh Meteor Garden. Rupanya tiap masa maskulinitas bergeser dan mengikuti tokoh publik yang ada.

Mitos: Bergesernya nilai maskulinitas di suatu wilayah dapat dilihat bagaimana media cenderung menampilkan tampang lelaki sebagai sosok masukulinitas. Melihat dari bagaimana media memunculkan tampang maskulin, di era wanita di Indonesia sering ditampilkan dengan wajah oriental, kulit putih, dan busana yang rapi. Hal tersebut dapat diuraikan melihat merambahnya dunia musik korea yang didominasi idol berwajah oriental dan berkulit putih bersih ke Indonesia. dulu Iwan meniru gaya tokoh dalam drama sekarang, tampang maskulin pujaan wanita-

\section{KESIMPULAN}

Tanda-tanda dominan yang muncul pada melihat makna lebih dalam serta mengungkap makna yang tersembunyi dibalik tanda-tanda yang dapat dianalisis dari 10 cuplikan adegan. Penelitian telah menujukan makna konotasi, denotasi atau bahkan mitos dari beberapa adegan yang dipilih menghasilkan makna-makna yang mengungkapkan dan memberikan pembenaran adanya nilai-nilai maskulinitas seorang laki-laki terbentuk akan latar belakang sosial, idola yang sedang hype dalam kurun waktu tersebut, bentuk fisik dan pakaian yang cenderung rapi, strata ekonomi kelas atas. Dari analisis menunjukkan terbentuknya analisis karakteristik new masculinity.

Berdasarkan hasil yang telah diteliti mengenai maskulinitas pada salah satu tokoh pembantu film Susah Sinyal menggunakan analisis Roland Barthes dengan tiga struktur, yakni analisis secara denotasi, konotas,dan mitos, penulis dapat menyimpulkan bahwa:

1. Nilai maskulinitas suatu wilayah dapat dilihat dari bagaimana media menampilkan model yang mengisi layar, hingga masyarakat dapat merepresentasikan maskulinitas yang dibawakan oleh sang model kedalam kehidupan sehari-harinya.

2. Nilai maskulinitas di tiap era atau zaman ke zaman lain tak bersifat statis, namun lebih dinamis. Walau hakikat seornag laki-laki cenderung cuek, namun maskulinitas di era kini dilambangkan dengan bagaimana seorang laki-laki dapat menempatkan diri dengan baik, peduli, menghargai orang sekitar, terlebih perempuan, dan menerima pendapat.

Windu, Riap. Isu Perempuan dalam Film Nasional.

https://www.kompasiana.com/riapwindhu/5 8f645e94d7a61f13d6d1fb1/isu-perempuandalam-film-nasional?page $=$ all

Stuart Hall, The Work of Representations, (London,Sage/the open University,1997

Sean Nixon, Exhibiting Masculinity, (London,Sage/The Open University,1997
Abdul Wahid, Moch. 2018 Pesan Moral Dalam Film Susah Sinyal karya Ernest Prakasa. Hal. 94-102. Program Studi Ilmu Komunikasi, Jurusan Broadcasting. Sekolah Tinggi Ilmu Komunikasi Prapanca. 
http://ejournal.iainpurwokerto.ac.id/index.php/k omunika/article/download/1306/1406/

https://media.neliti.com/media/publications/167 169-ID-representasi-perempuan-dalamindustri-si.pdf

https://www.liputan6.com/showbiz/read/322184 4/susah-sinyal-raih-2-juta-penonton-ernestprakasa-dipuji.

\section{PROFIL PENULIS}

Jusuf Fadilah

Seorang Kaprodi dan Dosen Program Studi Periklanan Fakultas Komunikasi dan Bahasa Universitas Bina Sarana Informatika.

\section{Widarti}

Staff LPPM dan Dosen Program Studi Periklanan Fakultas Komunikasi dan Bahasa Universitas Bina Sarana Informatika

\section{Dina Andriana}

Dosen Program Studi Periklanan Fakultas Komunikasi dan Bahasa Universitas Bina Sarana Informatika 